\title{
Efektifitas penambahan Vitamin E pada pakan dalam meningkatkan pertumbuhan benih udang windu (Penaeus monodon) [The effectiveness of adding Vitamin $\mathrm{E}$ to feed in increasing the growth of tiger shrimp (Penaeus monodon)]
}

\author{
Mukhlis $^{1^{*}}$, Rindhira Humairani ${ }^{1}$, Yusrizal Akmal' ${ }^{1}$ Irfannur ${ }^{1}$
}

\section{${ }^{1}$ Program Studi Akuakultur, Fakultas Pertanian Universitas Almuslim. Jln. Almuslim Matangglumpangdua, Bireuen-Aceh}

ABSTRACT | Research is aim to determine the effect of vitamin $\mathrm{E}$ among the treatment of seed growth rate of black tiger shrimp (Penaeus monodon). Feed is one of the biological factors that are important to the shrimp, therefore, the addition of vitamin $\mathrm{E}$ in the diet is known to act as anti-oxidants, which is able to maintain the availability of HUFA. The research was conducted in the village of Muara Batu Meunasah Aron. Based on least significant difference test with the level of efficiency of feeding affects the growth of tiger prawn seed with the average value is highest in treatment $\mathrm{D}$ (13.853 grams), whereas the lowest in treatment A (9.758 grams ). For daily length growth rate is highest in $\mathrm{C}(0.682$ grams), whereas the lowest in treatment A $(0.567 \mathrm{~g})$. Weight growth is highest in treatment $\mathrm{C}(3.722 \mathrm{~g})$ and the lowest in treatment $\mathrm{A}$ $(0.567 \mathrm{~g})$. Least significant difference test at the rate of tiger shrimp molting seed with the addition of vitamin $\mathrm{E}$ in the artificial diet affects the growth of the seed with the highest tiger shrimp are also present in treatment $\mathrm{D}$ that is without the addition of vitamin $\mathrm{E}$, which had a top speed of molting namely (43.3\%). The highest survival rate are in treatment C (100\%) and the lowest in treatment D (92.67\%).

Key words $\mid$ Vitamin E, growth, survival, seed tiger shrimp

ABSTRAK | Penelitian bertujuan untuk mengetahui pengaruh penambahan vitamin E diantara perlakuan terhadap tingkat pertumbuhan benih udang windu (Penaeus monodon). Pakan merupakan salah satu faktor biologis yang penting bagi udang, oleh sebab itu penambahan vitamin $\mathrm{E}$ dalam pakan diketahui dapat berperan sebagai anti oksidan, yang mampu menjaga ketersediaan HUFA. Penelitian ini dilaksanakan di Desa Meunasah Aron Kecamatan Muara Batu. Berdasarkan uji Beda Nyata Terkecil dengan tingkat efesiensi pemberian pakan sangat berpengaruh terhadap pertumbuhan benih udang windu dengan nilai Rata-rata yang tertinggi terdapat pada perlakuan D (13,853 gram), sedangkan yang terendah pada perlakuan A (9,758 gram). Untuk laju pertumbuhan panjang harian yang tertinggi terdapat pada $\mathrm{C}$ (0,682 gram), sedangkan yang terendah pada perlakuan A (0,567 gram). Pertumbuhan bobot tertinggi terdapat pada perlakuan C (3,722 gram) dan terendah pada perlakuan A (0,567 gram). Uji Beda Nyata Terkecil dengan tingkat kecepatan molting benih udang windu dengan penambahan vitamin $\mathrm{E}$ dalam pakan buatan sangat berpengaruh terhadap pertumbuhan benih udang windu yang tertinggi juga terdapat pada perlakuan D yaitu tanpa penambahan vitamin E, yang memilki kecepatan molting yaitu (43,3\%). Kelangsungan hidup tertingi terdapat pada perlakuan C (100\%) dan terendah pada perlakuan D (92,67\%).

Kata kunci | Vitamin E, pertumbuhan, kelangsungan hidup, benih udang windu

Received | 27 September 2020, Accepted | 24 Oktober 2020, Published | 15 November 2020.

*Koresponden/ Mukhlis, Program Studi Akuakultur, Fakultas Pertanian Universitas Almuslim. Jln. Almuslim Matangglumpangdua, Bireuen-Aceh. Email: mukhlis@gmail.com

Kutipan|Mukhlis, M., Humairani, R., Akmal, Y., \& Irfannur, I. (2020). Efektifitas penambahan Vitamin E pada pakan dalam meningkatkan pertumbuhan benih udang windu (Penaeus monodon). Arwana: Jurnal Ilmiah Program Studi Perairan, 2(2), 123-129.

ISSN (Media Cetak) | 2657-0254

\section{PENDAHULUAN}

Udang windu (Penaeus monodon Fab) merupakan komoditas unggulan Indonesia dalam upaya menghasilkan devisa negara dari ekspor non migas. Berbagai upaya telah dilakukan dalam meningkatkan produksi udang windu. Salah satu diantaranya penerapan sistem budidaya udang windu secara intensif yang dimulai sejak pertengahan tahun 1986 (Pratiwi, 2018). Keberhasilan usaha pembenihan udang windu merupakan langkah 
awal dalam sistem matarantai budidaya. Keberhasilan pembenihan tersebut pada akhirnya akan mendukung usaha penyediaan benih udang windu yang berkualitas. Salah satu faktor yang sangat menentukan kualitas udang windu yang dihasilkan adalah faktor pakan.

Pakan adalah salah satu faktor biologis yang penting bagi udang. Ketersediaan pakan berpengaruh besar terhadap pertumbuhan dan kelangsungan hidup udang windu. Oleh karena itu persediaan pakan merupakan salah satu persyaratan mutlak bagi berhasilnya pembenihan udang (Putri, 2020). Usaha pembenihan udang umumnya menggunakan pakan alami, sebagai pakan utama. Penggunaan pakan alami memiliki masalah dalam ketersediaan yang dipengaruhi oleh musim dan cuaca alam. Sehingga diperluhkan alternatif pakan lain untuk menutupi dan mengisi ketersediaan pakan alami tersebut. Penelitian ini memberikan pakan alternatif lain untuk pembenihan merupa campuran antara vitamin E dan pakan pelet dengan dosis yang berbeda.

Pemberian vitamin E dalam pakan diketahui dapat berperang sebagai anti oksidan, yang mampu menjaga ketersediaan HUFA (Highly unsaturated fatty acids) yang merupakan suatu komponen yang harus dimiliki oleh setiap spesies, yang tergolong dalam lemak esensial. Dalam membran sel dapat mencegah terjadinya radikal bebas intraseluler, sehingga pengkayaannya dalam pakan dapat pula beperan penting dalam pertumbuhan dan kelulushidupan udang windu dikarenakan metabolisme dapat berjalan dengan baik.

Dosis penentuan pemberian vitamin $\mathrm{E}$ dalam pakan uji didasarkan hasil penelitian yang telah dilakukan oleh Ricky Septian et al,. (2013) dimana dosis $0,20,40$ dan $60 \mathrm{mg} / \mathrm{kg}$ pakan dapat memberikan tingkat pertumbuhan dan kelulushidupan kepiting soka. Berdasarkan latar belakang inilah dapat diidentifikasikan permasalahan dari benih udang windu yaitu belum di ketahui seberapa besar efektivitas penambahan vitamin $\mathrm{E}$ pada pakan dalam meningkatkan pertumbuhan udang windu (Penaeusmonodon). Penelitian ini bertujuan untuk mengetahui pengaruh penambahan vitamin $\mathrm{E}$ pada pakan komersial dalam meningkatkan pertumbuhan benih udang windu.

\section{BAHAN DAN METODE}

Penelitian ini dilaksanakan di Desa Meunasah Aron yang bertempat di Hatchery UD. Bahari. Metode yang digunakan dalam penelitian ini adalah metode kualitatif dengan memberikan perlakuan pada masing-masing ember penelitian berupa vitamin $\mathrm{E}$ yang berbeda. Metode yang digunakan dalam penelitian ini adalah Rancangan Acak Lengkap (RAL) non faktorial dengan empat perlakuan dan tiga ulangan.Penelitian ini menggunakan konversi dari penelitian Ricky Septian et al , (2013). Adapun perlakuan dalam penelitian ini yaitu : Perlakuan $\mathrm{A}=$ Penambahan vitamin $\mathrm{E}$ dengan dosis $5 \mathrm{mg} / \mathrm{Kg}$ pakan pelet Perlakuan $\mathrm{B}=$ Penambahan vitamin E dengan dosis $10 \mathrm{mg} / \mathrm{Kg}$ pakan Perlakuan $\mathrm{C}=$ Penambahan vitamin $\mathrm{E}$ dengan dosis $15 \mathrm{mg} / \mathrm{Kg}$ pakan pelet Perlakuan $\mathrm{D}=$ Kontrol (Tanpa vitamin $\mathrm{E}$ )

\section{Prosedur Penelitian}

Hal yang pertama dilakukan adalah menyiapkan wadah dan peralatan yang digunakan. Wadah yang digunakan berupa ember berkapasitas 30 liter dan berjumlah 12 wadah. Wadah dan peralatan yang digunakan terlebih dahulu disucihamakan dengan menggunakan deterjen. Wadah yang telah disiapkan kemudian diisi air laut. Setelah itu benih udang windu dimasukkan kedalam ember dan wadah penelitian diaerasi terus menerus untuk menjamin suplai oksigen terlarut.

\section{Pemberian Pakan}

Pakan yang diberikan adalah pakan benih udang windu berbentuk pelet tenggelam, sedangkanVitamin E yang digunakan adalah vitamin E komersial yang berbentuk pil. Pada ikan uji tersebut kemudian dicampur dengan vitamin $\mathrm{E}$ yang dilarutkan terlebih dahulu dalam alkohol 70\%, total alkohol yang dilarutkan perwadah adalah 10 mldan kemudian disemprotkan pada pakan dengan sprayer. Pakan yang telah dicampurkan vitamin dikeringkan diudara untuk menguapkan alkohol.Dosis vitamin E yang ditambahkan antara lain 5, 10dan $15 \mathrm{mg} / \mathrm{kg}$ pakan, sebagai kontrol penelitian diberikan pakan pelet yang tidak yang tidak ditambahkan vitamin $\mathrm{E}$ Selama masa pemeliharaan 1 bulan, udang windu akan diberi pakan pelet sebanyak $15 \%$ dari berat tubuh perhari. Pemberian pakan dilakukan 4 kali sehari, yaitu pada pagi, 
siang,sore dan malam hari. Setiap 3 hari sekali akan dilakukan penyiponan. Selama masa perlakuan akan diamati, pertumbuhan panjang, bobot dan kelangsungan hidup, serta diukur parameter kualitas airnya (suhu, DO, pH).

\section{Efesiensi Pemberian Pakan}

Efisiensi pakan menunjukkan jumlah pakan yang dicerna oleh benih udang windu untuk kebutuhan hidup dan pertumbuhannya, efisiensi pakan di hitung berdasarkan biomassa benih udang windu pada akhir penelitian dengan biomassa pada awal penelitian dibandingkan dengan jumlah pakan yang diberikan berdasarkan rumus Leye (2009).

\section{Kecepatan molting}

Pengamatan secara visual dilakukan setiap hari untuk mengontrol perkembangan jam setelah terjadi moltingbenih udang winduuji setelah pemberian pakan sampai udang uji tersebut mengalami molting. Satu jam setelah molting, dilakukan pengambilan data akhir dengan melihat jumlah benih udang yang molting.

\section{Survival Rate (SR)}

Pengamatan jumlah benur yang hidup dilakukan pada awal dan akhir penelitian dengan cara menghitung seluruh jumlah benih yang masih hidup, yaitu dengan menggunakan rumus Effendie, (1997).

\section{Perhitungan Panjang}

Pertumbuhan panjang diamati diawal, pertengahan, dan diakhir penelitian selama 1 bulan.Pertumbuhan panjang udang windu dihitung berdasarkan pertambahan panjang seperti yang dikemukakan oleh Effendi (1997).

\section{Pertambahan Bobot}

Pertambahan bobot udang winduditimbang diawal, pertengahan dan diakhir penelitian selama 1 bulan. Penimbangan dilakukan dengan menggunakan timbangan analitik dengan cara memasukkan biota uji kedalam wadah lalu diletakkan di atas timbangan analitik. Pertumbuhan bobot dihitung dengan rumus Effendie (2004).

\section{Analisa Data}

Data yang diperoleh dari pengamatan disajikan dalam bentuk tabel dan grafik kemudian dianalisa dengan uji F (Anova). Apabila F hitung lebih besar nilainya dibandingkan $\mathrm{F}$ tabel berarti berbeda nyata dan diuji lanjut dengan menggunakan Uji Beda nyata jujur (BNT) pada taraf 0.05, (Hanafiah, 1989).

\section{HASIL}

\section{Efisiensi Pakan}

Efisiensi pakan adalah kemampuan untuk mengubah pakan kedalam bentuk tambahan bobot badan. Efisiensi pakan tergantung kepada aktivitas fisiologi ikan (organisme). Untuk lebih jelas efisiensi pemberian pakan dari hari pertama sampai 30 hari disajikan dalam Gambar 1 berikut ini:

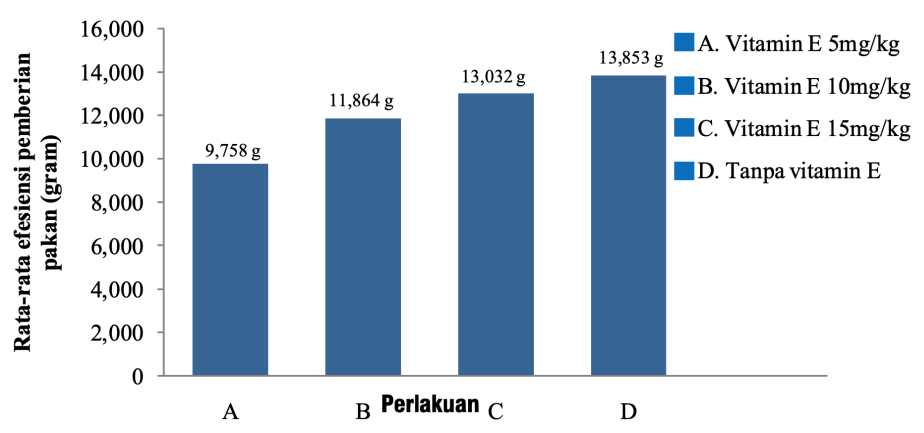

Gambar 1. Rata-rata Efesiensi Pemberian Pakan Benih Udang Windu

Dari Gambar 1 diatas dapat disimpulkan bahwa penambahan vitamin $\mathrm{E}$ pada pakan buatan sangat berpengaruh terhadap peningkatan efesiensi dan pertumbuhan benih udang windu. Efesiensi pemberikan pakan yang terbaik terdapat pada perlakuan D sebagai kontrol yang tidak ditambahkan vitamin $\mathrm{E}$ dengan nilai ratarata (13,853 gram), dan yang paling rendah terdapat pada perlakukan A dengan penambahan vitamin E sebanyak ' $10 \mathrm{mg} / \mathrm{kg}$ dengan nilai rata-rata $(9,758$ gram). Dari hasil analisis variansi menghasilkan hasil yang sangat berbeda nyata, dimana $\mathrm{F}_{\text {hitung }} 545,367>\mathrm{F}$ tabel 7,5 pada $\propto=0,01$.

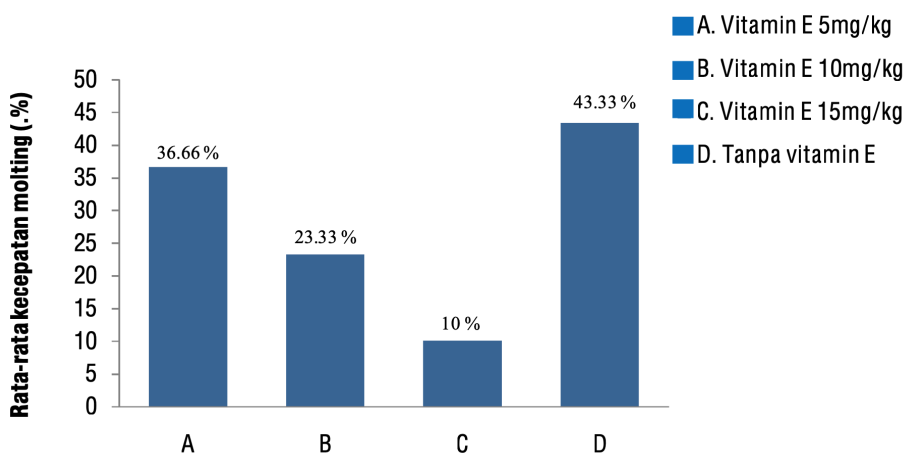

Gambar 2. Rata-rata Tingkat Kecepatan Molting Benih Udang Windu Dengan Penambahan Vitamin E Pada Pakan Buatan. 


\section{Kecepatan Molting}

Molting didefinisikan sebagai perubahan udang dalam berat, ukuran, maupun volume seiring dengan berubahnya waktu. Hasil pengukuran kecepatan molting benih udang windu dapat dilihat pada Gambar 2. Hasil penelitian menunjukkan bahwa kecepatan molting dengan penambahan vitamin $\mathrm{E}$ pada pakan buatan yang tertinggi terdapat pada perlakuan $\mathrm{D}$ dengan nilai rata-rata $(43,33 \%)$. Sedangkan kecepatan molting terendah terdapat pada perlakuan $\mathrm{C}$ yaitu ditambahkan vitamin $\mathrm{E}$ dengan nila rata-rata (10\%). Dari hasil analisis variansi menghasilkan hasil yang sangat berbeda nyata, dimana $\mathrm{F}$ hitung $9,34>\mathrm{F}$ tabel 7,5 pada $\propto=0,01$. Hal ini menunjukkan bahwa penambahan vitamin Epada pakan dapat mempercepat kecepatan molting benih udang windu.

\section{Suvival Rate (SR)}

Dari hasil uji sidik ragam menunjukkan bahwa kelangsungan hidup benih udangwindu tidak berbeda nyata antar perlakuan $(\mathrm{P}<0,05)$ akibat penambahan vitamin $\mathrm{E}$ pada pakan buatan yang diberikan selama 30 hari cendrung sama. Untuk lebih jelas tingkat kelangsungan hidup benih udang windu akibat penambahan vitamin $\mathrm{E}$ pada pakan buatan yang diberikan selama 30 hari di sajikan dalam Gambar 3 berikut ini:

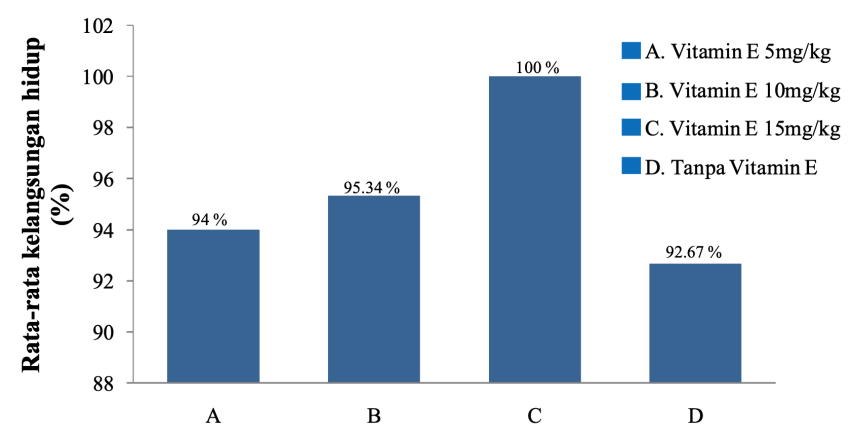

Gambar 3. Rata-rata Tingkat Kecepatan Molting Benih Udang Windu Dengan Penambahan Vitamin E Pada Pakan Buatan.

Berdasarkan Gambar 3 menunjukkan bahwa tingkat kelangsungan hidup yang tertinggi pada perlakuan C (100\%), selanjutnya pada perlakuan B dengan nilai rata-rata $(95,34 \%)$, kemudian pada perlakuan A sebanyak (94\%), dan yang terendah pada perlakuan D yaitu sebanyak $(92,67 \%)$.

\section{Perhitungan Panjang}

Pertumbuhan panjang benih udang windu merupakan suatu gejala yang menunjukkan bahwa adanya perkembangan bentuk dari awal menjadi bertambah pada akhir pengamatan. Pertambahan panjang ditunjukkan dengan adanya penambahan ukuran badan benih udang windu seperti yang terlihat pada Gambar 4 berikut ini:

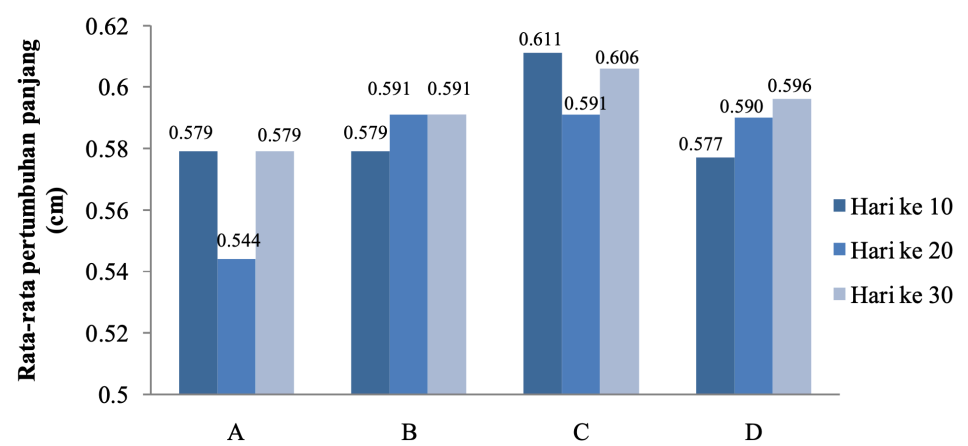

Gambar 4. Rata-rata Tingkat Pertumbuhan PanjangBenih Udang Windu Dengan Penambahan Vitamin E Pada Pakan.

Hasil penelitian menunjukkan bahwa rata-rata tingkat pertumbuhan panjang benih udang windu dengan penambahan vitamin $\mathrm{E}$ pada pakan buatan yang tertinggi terdapat pada perlakuan $\mathrm{C}$ dengan dosis vitamin $\mathrm{E} 15 \mathrm{mg} / \mathrm{kg}$ sebesar pada hari ke $10(0,611 \mathrm{~cm})$, hari ke 20 $(0,591 \mathrm{~cm})$ dan hari ke $30(0,606 \mathrm{~cm})$, sedangkan yang terendah pada perlakuan A dengan dosis penambahan vitamin E $5 \mathrm{mg} / \mathrm{kg}$ dengan nilai rata-rata hari ke $10(0,579 \mathrm{~cm})$, hari ke $20(0,544$ $\mathrm{cm})$ dan hari ke $30(0,579 \mathrm{~cm})$.

\section{Pertambahan Bobot}

Tingkat pertambahan bobot benih udang windu akibat penambahan vitamin $\mathrm{E}$ pada pakan buatan menunjukkan hasil yang berbeda. Ratarata tingkat pertumbuhan bobot benih udang windu setelah penambahan vitamin $\mathrm{E}$ pada pakan buatan dapat dilihat pada gambar berikut ini:

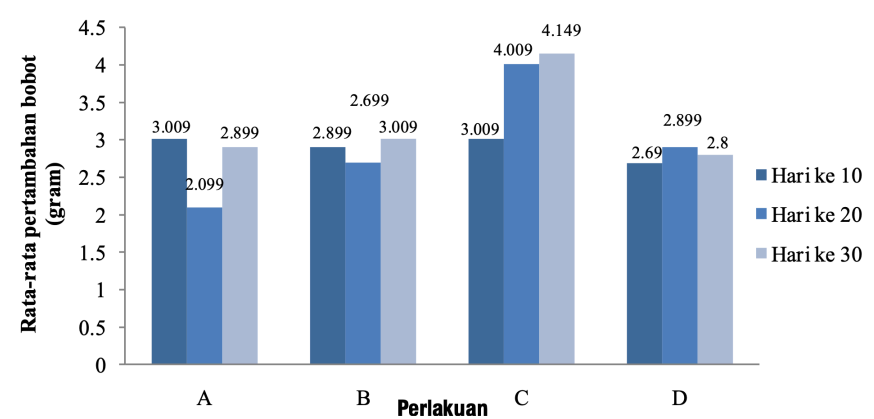

Gambar 5. Rata-rata Tingkat Pertambahan Bobot Benih Udang Windu Dengan Penambahan Vitamin E Pada Pakan. 
Dari Gambar 5 menunjukkan perbedaan pertambahan bobot pada tiap-tiap perlakuan. Pertumbuhan bobot tertinggi terdapat pada perlakuan $\mathrm{C}$ dengan dosis vitamin $\mathrm{E} 15 \mathrm{mg} / \mathrm{kg}$ sebesar pada hari ke 10 (3,009 gram), hari ke 20 (4,009 gram), dan hari ke 30 (4,149 gram), sedangkan yang terendah pada perlakuan $\mathrm{D}$ sebagai kontrol tanpa penambahan vitamin $\mathrm{E}$ dengan nilai rata-rata hari ke 10 (2,69 gram), hari ke 20 (2,89 gram), dan hari ke $30(2,89$ gram).

\section{PEMBAHASAN}

Efisiensi pakan berkaitan erat dengan rataan pertambahan bobot badan harian dan konsumsi.Efisiensi penggunaan pakan merupakan perbandingan dari rataan pertambahan bobot badan dengan konsumsi pakan, efisiensi penggunaan pakan yang mengandung protein tinggi, lebih tinggi dibandingkan dengan pakan yang mengandung protein rendah. Hal ini sangat mendukung terhadap pertumbuhan yang mengutamakan protein sebagai kandungan bahan pakan dimana pada akhirnya memberikan dampak yang lebih baik pada ikan untuk meningkatkan pertambahan bobot badan yang diharapkan. Penambahan vitamin $\mathrm{E}$ dalam pakan dapat memberikan tingkat pertumbuhan yang baik terhadap benih udang windu. Kandungan zat makanan yang buruk akan menyebabkan efisiensi pakan yang buruk. Nilai rata-rata yang tertinggi terdapat pada perlakuan D (kontrol) karena pada pakan mengandung protein yang sudah ditentukan dan dapat bermanfaat terhadap efesiensi pakan.

Faktor yang terpenting penentu efesiensi pemanfaatan pakan adalah jenis dan komposisi pakan yang sesuai dengan kebutuhan ikan, dan juga harus sesuai dengan ketersedian enzim dalam pecernaan ikan. Pakan yang diberikan harus mempertimbangkan kebutuhan suatu spesies udang yang dipelihara diantaranya kebutuhan protein, karbonhidrat, lemak, vitamin, dan mineral (Agustono, 2013). Menurut Simanjuntak (2016), nilai energi yang diperhitungkan biasa disebut dengan energi metabolisme. Energi metabolisme ini diperoleh setelah nutrien utama karbonhidrat, lemak, dan protein mengalami beberapa proses kimia seperti katabolisme dan oksidasi dalam tubuh ikan.
Hasil penelitian menunjukkan bahwa perlakuan D tanpa pemberian vitamin E pada pakan buatan memberikan hasil terbaik dalam menginduksi molting benih udang windu, hasil diatas dapat disimpulkan bahwa pemberian pakan buatan sebaiknya mempunyai kadar nutrien yang seimbang. Berdasarkan uji yang telah dilakukan terbukti bahwa dengan ada atau tidaknya penambahan vitamin $\mathrm{E}$ dalam pakan buatan dapat mempercepat molting dan meningkatkan pertumbuhan, hasil ini hampir sesuai dengan pendapat Fujaya et,al., (2009).

Tingkat kelangsungan hidup adalah jumlah ikan yang hidup hingga akhir pemeliharaan. Adapun faktor-faktor yang dapat mempengaruhi tingkat kelangsungan hidup antara lain lingkungan, kualitas air, $\mathrm{pH}$, kekeruhan, suhu, dan oksigen terlarut. Selain dari itu, faktor makanan dan predator juga bisa menurunkan tingkat kelangsungan hidup ikan. Benih udang windu setelah penambahan vitamin $\mathrm{E}$ pada pakan buatan berbeda antar perlakuan A, B, C dan D. Hal ini menandakan bahwa setelah penambahan vitamin $\mathrm{E}$ pada pakan buatan lebih baik kelangsungan hidup dan pertumbuhannya dibandingkan tanpa penambahan vitamin $\mathrm{E}$ pada pakan buatan. Pemanfaatan vitamin E juga dapat mengatasi suatu langkah yang tepat untuk kebutuhan udang. Kelangsungan hidup benih udang windu yang terbaik terdapat pada perlakuan $\mathrm{C}$ dengan penambahan vitamin $\mathrm{E}$ sebanyak $15 \mathrm{mg} / \mathrm{kg}$. Dengan penambahn vitamin E $15 \mathrm{mg} / \mathrm{kg}$ dapat meningkatkan daya tahan tubuh benih udang windu, membantu mengatasi stress dan sebagai antioksidan (Steffens ,1989). Kandungan toksisitas yang tinggi dapat mempengaruhi abnormalitas larva (Muliari et al., 2020).

Dari hasil uji sidik ragam menunjukkan bahwa pertumbuhan panjang benih udang windu sangat berpengaruh antar perlakuan dengan penambahan vitamin $\mathrm{E}$ pada pakan buatan yang diberikan selama 30 hari. Dengan penambahan vitamin $\mathrm{E}$ sebanyak $15 \mathrm{mg} / \mathrm{kg}$ dapat mempercepat pertumbuhan panjang ikan yang terbaik, sedangkan yang terendah terdapat pada perlakuan A dengan penambahan dosis vitamin E yang sedikit yaitu $5 \mathrm{mg} / \mathrm{kg}$. Menurut Tacon (1987), organisme mengunakan protein sebagai sumber energi bersama karbonhidrat, kelebihan tingkat protein atau protein efficiency ratio yang tinggi dalam pakan menghasilkan penekanan laju pertumbuhan, energi yang 
tersisa untuk pertumbuhan, akan naik secara proposional dengan meningkatkan energi pakan yang diberikan sampai akhirnya mencapai titik keseimbangan, sehingga energi pakan akan digunakan untuk pertumbuhan. Perkembangan juga terjadi pada tahap embrio dan larva sangat membutuhkan nutrien yang sangat tinggi untuk melewati setiap tahapan perkembangan (Akmal dan Mahfud, 2020).

Dari hasil uji sidik ragam menunjukkan bahwa pertambahan bobot benih udang windu tidak berpengaruh antar perlakuan dengan penambahan vitamin $\mathrm{E}$ pada pakan buatan yang diberikan selama 30 hari, dengan nilai hitung 221,517. Dengan penambahan vitamin E sebanyak $15 \mathrm{mg} / \mathrm{kg}$ dapat mempercepat pertumbuhan bobot ikan yang terbaik, sedangkan yang terendah terdapat pada perlakuan A dengan penambahan dosis vitamin E yang sedikit yaitu $5 \mathrm{mg} / \mathrm{kg}$. Menurut Kanazawa (1985), vitamin E sangat berperan dalam pakan, karena dalam vitamin $\mathrm{E}$ banyak terdapat asam lemak tak jenuh. Asam lemak tak jenuh (HUFA) dalam pakan udang merupakan komponen yang penting yang diketahui sebagai antioksidan. Agar asam lemak esensial digunakan dengan baik oleh udang maka penambahan vitamin $\mathrm{E}$ dalam pakan memainkan peranan yang penting dalam pertumbuhan. Maka diduga bahwa pemberian vitamin $\mathrm{E} 15 \mathrm{mg} / \mathrm{kg}$ dapat meningkatkan nafsu makan benih udang windu. Hal ini dijelaskan oleh Rachmawati (2014), bahwa jenis pakan yang dapat diberikan untuk pembesaran udang windu memberikan pengaruh terhadap pertumbuhanya karena kandungan protein didalamnya.

\section{KESIMPULAN}

Dari hasil penelitian yang telah dilakukan tentang penambahan vitamin $\mathrm{E}$ pakan buatan terhadap pertumbuhan benih udang windu dapat disimpulkan sebagai berikut: Efesiensi pemberian pakan yang paling tinggi terdapat pada perlakuan Dyang tidak ada penambahan Fitamin E dalam Pakan buatan, dalam pakan buatan, begitu juga kecepatan molting yang paling tinggi terdapat pada perlakuan $\mathrm{D}$ dengan nilai rata-rata $(36,66 \%)$ dan yang terendah pada perlakuan Cyang ada penambahan vitamin Edengan nilai rata-rata (10 \%). Perhitungan panjang yang tertinggi terdapat pada perlakuan
C dengan dosis vitamin $\mathrm{E} 15 \mathrm{mg} / \mathrm{kg}$ sebesar pada hari ke $10(0,611 \mathrm{~cm})$, hari ke $20(0,591 \mathrm{~cm})$ dan hari ke $30(0,606 \mathrm{~cm})$, sedangkan yang terendah pada perlakuan A dengan dosis penambahan vitamin E $5 \mathrm{mg} / \mathrm{kg}$ dengan nilai rata-rata hari ke $10(0,579 \mathrm{~cm})$, hari ke $20(0,544$ $\mathrm{cm})$ dan hari ke $30(0,579 \mathrm{~cm})$. Pertumbuhan bobot tertinggi terdapat pada perlakuan $\mathrm{C}$ dengan dosis vitamin E $15 \mathrm{mg} / \mathrm{kg}$ sebesar pada hari ke 10 (3,009 gram), hari ke 20 (4,009 gram), dan hari ke 30 (4,149 gram), sedangkan yang terendah pada perlakuan D sebagai kontrol tanpa penambahan vitamin $\mathrm{E}$ dengan nilai ratarata hari ke 10 (2,69 gram), hari ke $20(2,89$ gram), dan hari ke 30 (2,89 gram).

\section{DAFTAR PUSTAKA}

Agustono, A., Putera, N. K., \& Subekti, S. (2013). Substitusi Tepung Bungkil Kedelai dengan Fermentasi Daun Lamtoro (Leucaena glauca) Terhadap Pertumbuhan dan Efisiensi Pakan Ikan Nila (Oreochromis niloticus). Jurnal Ilmiah Perikanan dan Kelautan, 5(2), 205-210.

Akmal, Y., \& Mahfud. (2020). Perkembangan Hewan. Intimedia, Malang.

Aslamyah, S., \& Fujaya, Y. (2009). Formulasi Pakan Buatan Khusus Kepiting yang Berkualitas Murah dan ramah Lingkungan. Jurna Sains \& Teknologi, Seri Imu-Ilmu Pertanian, $9(2)$, 133141.

Effendi, I. (2004). Pengantar akuakultur. Penebar Swadaya. Jakarta, 188.

Effendie, M. I. (1997). Biologi perikanan. Yayasan Pustaka Nusatama. Yogyakarta, 163.

Hanafiah, K. A. (1989). Pengaruh Pupuk Kandang dan Kapur terhadap Agihan Bentuk dan Ketersediaan P pada Tanah Latosol (Doctoral dissertation, Thesis S2 Bidang Kimia dan Kesuburan Tanah. PS Ilmu Tanah. PPS-UGM. Yogyakarta).

Kanazawa, K. K., \& Gordon, J. G. (1985). Frequency of a quartz microbalance in contact with liquid. Analytical Chemistry, 57(8), 1770-1771.

Leye, V. (2009). Information and communication technologies for development: A critical perspective. Global Governance: A Review of Multilateralism and International Organizations, 15(1), 29-35.

Muliari, M., Zulfahmi, I., Akmal, Y., Karja, N. W. K., Nisa, C., Sumon, K. A., \& Rahman, M. M. (2020). Toxicity of palm oil mill effluent on the early life stages of Nile tilapia (Oreochromis niloticus, Linnaeus 1758). Environmental Science and Pollution Research, 27, 3059230599.

Pratiwi, R. (2018). aspek biologi dan ablasi mata pada 
udang windu penaeus monodon suku penaeidae (decapoda: malacostraca). OSEANA, 43(2), 3447.

Putri, T., Supono, S., \& Putri, B. (2020). Pengaruh jenis pakan buatan dan alami terhadap pertumbuhan dan kelangsungan hidup larva udang vaname (Litopenaeus vannamei). Jurnal Akuakultur Rawa Indonesia,, 8(2), 176-192.

Rachmawati, D., \& Samidjan, I. (2014). pengkayaan pakan buatan melalui penambahan vitamin e terhadap performan efisiensi pemanfaatan pakan, laju pertumbuhan relatif dan kelulushidupan kepiting bakau (Scylla paramamosain). Pena Jurnal Ilmu Pengetahuan dan Teknologi, 27(2), 169-185.

Septian, R., Samijan, I., \& Rachmawati, D. (2013). Pengaruh Pemberian kombinasi pakan ikan rucah dan buatan yang diperkaya vitamin $\mathrm{E}$ terhadap pertumbuhan dan kelulushidupan kepiting soka (Scylla paramamosain). Journal of Aquaculture Management and Technology, 2(1), 13-24.

Simanjuntak, I. C. B. H., \& Sudaryono, A. (2016). Pengaruh Konsentrasi Bakteri Probiotik yang Berasosiasi dalam Usus Sebagai Bioflok terhadap Efisiensi Pemanfaatan Pakan, Pertumbuhan dan Kelulushidupan Lele Dumbo (Clarias gariepinus). Journal of Aquaculture Management and Technology, 5(2), 1-8.

Steffens, W. (1989). Principles of fish nutrition. Ellis Horwood Limited.

Tacon, A. G. (1987). The nutrition and feeding of farmed fish and shrimp a training manual: the essential nutrients (No. 639.2085 T32). FAO. 